\title{
Rodzinne opresje Julianny Młodeckiej (1731-ok. 1799). Przyczynek do dziejów przemocy domowej w czasach staropolskich
}

\begin{abstract}
Słowa kluczowe: przemoc domowa, sądownictwo szlacheckie, własność ziemska, Dłużewski Antoni, Dzierżanowski Antoni, Młodecki Aleksander, Wydżga Michał

Key words: domestic abuse, nobility courts, landed estate, Dłużewski Antoni, Dzierżanowski Antoni, Młodecki Aleksander, Wydżga Michał
\end{abstract}

Problem przemocy w rodzinie w czasach staropolskich rzadko dotąd był tematem badań ${ }^{\text {. }}$ W jeszcze większym stopniu dotyczy to agresji wobec dzieci, na temat której brak jakiejkolwiek literatury. Wynika to nie tylko ze skąpości źródeł, ale głównie z faktu, że ówcześnie bicie dziecka w zasadzie nie podlegało karaniu prawem i w konsekwencji niemal nie znajduje odzwierciedlenia w aktach sądowych. Przeciwnie, stosowanie kar cielesnych zarówno w szkole, jak i w domu było czymś normalnym, powszechnie tolerowanym i aprobowanym, a nawet uważanym za konieczne w celach wychowawczych, zwłaszcza w przypadku synów. To raczej brak surowego wychowania i dyscyplinowania uważano za przejaw nieodpowiedzialnego traktowania potomstwa, mogącego prowadzić do przykrych następstw. Przestrzegano tylko przed nadmiernym okrucieństwem i biciem w złości, przykazywano zatem, aby „karać z miłości, lecz nie z gniewem"2. Takie przypadki brutalności ganiono, aczkolwiek nadal uznawano je za należące do sfery czysto prywatnej, więc z reguły nie wychodziły one poza krąg rodziny. Nie była też de iure możliwa jakakolwiek niesądowa ingerencja z zewnątrz, która mogłaby być wręcz traktowana na równi z naruszeniem miru domowego. Znęcanie się nad dziećmi i innymi członkami rodziny poniekąd ograniczały tylko zasady religijne, a ściślej bojaźń boża i wiara w karę za grzech, za jaki uznawano takie postępowanie ${ }^{3}$. Nawet Prawo cywilne narodu polskiego w rozdziale IV o przestępstwach i karach, wśród licznych kategorii przestępstw prywatnych w ogóle nie uwzględnia tej kwestii ${ }^{4}$. Niekiedy jednak skrajne przypadki okrucieństwa ostatecznie trafiały na wokandy sądowe, aczkolwiek wyłącznie wtedy, gdy ich nagłośnienie i zaakcentowanie mogło być wykorzystane np. do rozgrywek majątkowych lub starań o unieważnienie małżeństwa, w związku z oskarżeniem o rapt.

Do takich zalicza się sprawa niezwykle brutalnego traktowania młodej szlachcianki, Julianny Młodeckiej, przez jej matkę Konstancję Wereszczakównę, primo voto Młodecką, secundo voto Chociszewską. Sporo informacji na ten temat znaleźć można w aktach grodzkich horodelskich z lat 1747-1749, dzięki opisaniu tych zdarzeń w manifestacjach Julianny i jej

\footnotetext{
${ }^{1}$ Penkała A. 2017; Popiołek B. 2014, s. 978-990; Popiołek B. 2015, s. 83-93; Popiołek B. 2018, s. 21-32.

2 Kitowicz J. 1985, s. 56-57, 68; Sarcevičiene J. 2014, s. 401; Żołądź-Strzelczyk D. 2014, s. 224-225; Żołądź-Strzelczyk D., Kabacińska-Łuczak K. 2012, s. 55.

${ }^{3}$ Mozgawa M., Wrzyszcz A. 2019, s. 76-77; Uruszczak W. 2015, s. 105.

${ }^{4}$ Zob. Ostrowski T. 1787, s. 331-378.
} 
świeżo poślubionego męża Michała Józefa Wydżgi ${ }^{5}$. Zawarte tam drastyczne, choć z natury rzeczy stosunkowo krótkie opisy, mogłyby być odebrane jako celowo wyolbrzymione i przekoloryzowane, bo takie przejaskrawienia często pojawiały się w tego typu aktach, dla uzyskania lepszego efektu psychologicznego. Ich poświadczenie uzyskujemy jednak od bliskich krewnych maltretowanej, tj. od brata Kajetana Młodeckiego, kanonika lwowskiego, oraz wuja Bogusława Wereszczaki, stolnika smoleńskiego, w komplanacji zawartej z Wydżgą ${ }^{6}$, a także $\mathrm{z}$ aktów konsystorza chełmskiego ${ }^{7}$. Większe znaczenie ma uwiarygodnienie i niejednokrotnie uszczegółowienie oskarżeń w nieco później oblatowanych przesłuchaniach świadków oraz obdukcji już częściowo zagojonych ran głowy pokrzywdzonej, przeprowadzonych przed tym sądem konsystorskim ${ }^{8}$. Warto podkreślić, iż troje z sześciu niewymienionych z nazwisk (oznaczonych tylko numerami) sług i poddanych matki Julianny, zeznając pod przysięgą, zasłaniało się może ze strachu, niepamięcią i niewiedzą lub stwierdzeniem, że o wszystkim tylko słyszeli, ale sami tego nie widzieli. Pozostali zaś całkowicie potwierdzili zarzuty wobec swej pani, dodając nowe szczegóły. Jeden z nich thumaczył, że w ten sposób kaja się i pragnie choć częściowo zmazać swą współwinę, jako że z nakazu uczestniczył w wymierzaniu kar cielesnych. Inny natomiast nie ukrywał, że ujawnia to z zemsty za nieludzkie traktowanie siebie przez dziedziczkę, co w jakimś stopniu mogłoby podważać jego bezstronność i wiarygodność.

Cała ta przykra i bulwersująca sprawa przez lata nie uzyskała swego prawnego rozwiązana. Pojawiła się dość nagle w 1747 r., gdy wreszcie zajął się nią Wydżga, podówczas podstoli bełski i pisarz grodzki horodelski, później sędzia grodzki horodelski i ziemski bełski ${ }^{9}$, a więc człowiek jak najbardziej w prawie biegły. Zaakcentowanie maltretowania jego małżonki w czasie panieństwa miało uzasadnić dramatyczną decyzję o jej ucieczce z domu i rychłe zamążpójście jako ratunek przed powrotem i karzącą ręką matki. Ta bowiem oskarżała Wydżgę o porwanie panny i żądała unieważnienia małżeństwa. Znamienne, że nigdy nie zaprzeczyła przedstawianemu wynaturzonemu traktowaniu córki. Widocznie uważała, że nie ma sensu negować czegoś, o czym wszyscy i tak doskonale wiedzieli, choć nie reagowali. Oczywiście Wydżga miał przy tym własny interes do załatwienia, chcąc tą drogą wymóc na teściowej wypłacenie spodziewanych sporych sum posagowych nowo poślubionej żony. Liczył też, że jego małżonka w przyszłości, po śmierci swego jedynego brata, księdza Kajetana, przejmie prawa do części znacznej fortuny Młodeckich. Treść pierwszych manifestacji wskazywałaby, że jeszcze nie w pełni orientował się w coraz bardziej pogarszającym się stanie tego majątku ${ }^{10}$, wynikłym głównie z niegospodarności i lekkomyślności drugiego męża teściowej, Józefa Chociszewskiego.

Żona Wydżgi, Julianna Młodecka, była średnią córką podczaszego bracławskiego, Aleksandra Józefa i jego drugiej żony Konstancji z Wereszczaków. O jej ojcu wiemy niewiele. Milczą o nim herbarze, z wyjątkiem lakonicznej wzmianki (że istniał) u S. Uruskiego, który zresztą błędnie przypisał mu urząd podczaszego łukowskiego ${ }^{11}$. Nie wymienia go T. Żychliński w całkiem

${ }^{5}$ APL, KgH RMO, ks. 48, k. 460-461v (manifestacja z 19 VI 1747 r.).

${ }^{6}$ APL, KgH RMO, ks. 49, s. 17-19 (komplanacja z 20 VI 1747 r., oblata z 1749 r.).

7 AAL, AKL, sygn. Rep 60 A 128, k. 349-350v, 356v-357, 365-366 (aktuaria z 4 IX, 16 X i 13 XI 1747 r.).

${ }^{8}$ APL, KgH RMO, ks. 48, k. 529-535 (interrogatoria z 11 IX 1747 r. w Krasnymstawie). W aktach konsystorskich nie nie ma tego protokołu z przesłuchań, jedynie w dekrecie z 11 XII 1747 r. znalazła się konkluzja oraz przysięga wnoszącego sprawę M. Wydżgi: „w te słowa [...]: przysięgam, że jako świadków w sprawie de raptu agitującej się, ani przez siebie ani przez subordynowane osoby nie korumpowałem, darowizną, obietnicami albo jakim respektem, ani do świadectwa groźbą, prośbą nie przymuszałem; tak mi Panie Boże dopomóż”, AAL, AKL, sygn. Rep 60 A 128, k. 375.

${ }_{9}$ Urzędnicy bełscy. 1992, nr 242, 273; Bondyra W. 2014, nr 135, 152, 258.

${ }^{10}$ APL, KgH RMO 48, k. 463v-464v, 539-539v, 539v-540.

${ }^{11}$ Uruski S. 1914, t. 11, s. 159. Tę błędną informację powtórzył Marek Woliński (Woliński M. 2011, s. 187). Nie notuje go spis urzędników łukowskich (zob. Urzędnicy lubelscy. 1991, s. 118). 
wiarygodnej jak na niego nocie o Młodeckich ${ }^{12}$. Jest to o tyle zaskakujące, że uchodził on przecież za ,posiadacza znacznej fortuny”"13 i był wierzycielem przedstawicieli wielu znacznych rodów, m.in. Butlerów, Jabłonowskich, Potockich, Radziwiłłów ${ }^{14}$, Sołtyków, Tarłów, a zwłaszcza Zamoyskich. W kilkunastu odnalezionych transakcjach finansowo-majątkowych występuje tylko pod imieniem Aleksander, bez żon ${ }^{15}$ i bez podania jakichkolwiek danych o pochodzeniu i rodzicach. Nie pojawia się także na kartach przejrzanych w archiwum kijowskim ksiąg grodzkich kijowskich i żytomierskich ${ }^{16}$. Skutkiem tego większość informacji o nim można czerpać jedynie z wyżej wspomnianych akt sądowych, w których stroną byli jego potomkowie i sukcesorzy. Najprawdopodobniej pochodził z kijowsko-bracławskiej linii rodu, piszącego się z Wielkiego Młodocina vel Młodecina w województwie sandomierskim ${ }^{17}$, pieczętującego się herbem Półkozic. Niektórzy jego przedstawiciele używali przydomku Stawisz. Z nadania królewskiego Młodeccy posiadali dość rozległe dobra Koszowata na pograniczu województw kijowskiego i bracławskiego $^{18}$. Nie udało się odnaleźć informacji, czyim synem był Aleksander. Pierwsze wzmianki o nim pochodzą z lat 1708 i 1711, gdy był towarzyszem chorągwi pancernej Stanisława Władysława Potockiego, strażnika litewskiego ${ }^{19}$. Zapewne już wówczas związał się interesami z Zamoyskimi. W 1713 r. wymieniany był jako zastawny posesor ordynackiej wsi Horyszów Lacki, zaś w 1715 r. bracia Zamoyscy odstąpili mu sumę 39.000 złp, trzy lata wcześniej zapisaną na dobrach Rudnik nad Sanem przez łowczego podolskiego, Mikołaja Sołtyka i innych sukcesorów wojewody lubelskiego, Aleksandra Adama Drzewickiego ${ }^{20}$. W latach 1719-1722 i 1731-1734 dzierżawił klucze krzeszowski i piskorowicki w ordynacji zamojskiej ${ }^{21}$. Przed rokiem 1721 za pożyczoną sumę 150.000 złp wziął w zastaw ordynacki klucz Goraj w województwie lubelskim od starosty płoskirowskiego, Tomasza Józefa Zamoyskiego, zaś w 1733 r. dobra te wróciły do Zamoyskich po układzie z następnym ordynatem Michałem Zdzisławem ${ }^{22}$. Równolegle, od roku 1721 w zastawie za 30.000 złp trzymał ordynackie wsie Potok Górny i Dolny z folwarkiem ${ }^{23}$, położone na północnym skraju ziemi przemyskiej. Ponadto na tej zasadzie od 1727 r. posiadał dobra Ulanów W województwie sandomierskim za 150.000 złp od późniejszego kasztelana lubelskiego, Józefa Franciszka Sołtyka, oraz od 1728 r. dobra Radzięcin w województwie lubelskim za 93.000 złp od starosty preńskiego, Marka Antoniego Butlera ${ }^{24}$. Najpoważniejszym i najtrwalszym nabytkiem

12 Żychliński T. 1880, t. 2, s. 219-223.

13 Encyklopedia kościelna. 1892, t. 18, s. 509-510; Zbudniewek J. 1994, s. 78-79.

14 Np. późniejszy hetman wielki litewski, Michał Kazimierz „Rybeńko” Radziwiłł, był mu winny wielką sumę 224.000 złp, APL, KgLZ, ks. 165, k. 12 (kwitacja z tej sumy z 1742 r.).

15 Jedyny raz, gdy druga żona Konstancja z Wereszczaków występuje w dokumentach wraz z nim, to układ z 28 XI 1731 r. w Kawęczynku z Jakubem Żelazo Piotrowskim, starościcem szczebrzeskim (APL, KgLZ, ks. 159, k. 106). Pod aktami transakcji zawsze podpisywał się tylko jako „A. Młodecki”, nawet gdy był już podczaszym bracławskim.

${ }^{16}$ CPAHUK, f. 2 (księgi kijowskie), op. 1, ks. 8-10, 16-23, f. 11 (księgi żytomierskie); op. 1, ks. 17-24, 27-28, f. 44 (księgi winnickie); op. 1, ks. 3-6. Księgi kijowskie są niekompletne, a zachowane winnickie zaczynają się dopiero od roku 1768.

17 Występujący na Wołyniu Mołodeccy pisali się z Wielkiej Mołodni (CPAHUK, f. 28 (Księgi gr. włodzimierskie), op. 1, ks. 141, k. 34v, 36). Może więc Uruski ma rację, twierdząc, że istniał odrębny ród Mołodeckich, rzekomo ,ppochodzący z rodziny kozackiej” (Uruski S. 1914, t. 11, s. 231-232).

18 Żychliński T. 1880, t. 2, s. 219; SGKP. 1883, t. 4, s. 486-487; Rolle J.A. 1892, s. 146.

19 APL, KgLZ, ks. 147, k. 182, ks. 149, k. 53-53v.

20 APL, KgLZ, ks. 151, k. 480-480v; Bondyra W. 2015, s. 165.

${ }^{21}$ APL, KgL RMO, ks. 259, k. 157-158v (kontrakt z 18 V 1731 r. w Zamościu).

22 AGAD, Zb. Czołow., sygn. 460, s. 4; APL, KgGZ, ks. 129, s. 496; APL, KgK RMO, ks. 47, k. 385-385v.

${ }^{23}$ APL, KgGR, ks. 113, s. 510-512, 513-520 (inwentarz); Stworzyński M. 1834, s. 49.

${ }^{24}$ APL, KgK RMO, ks. 51, k. 721v; APL, KgLZ, ks. 161, k. 360v-361v (kontrakt z 24 VI 1728 r. w Radzięcinie). 
Aleksandra Młodeckiego były dobra nowosielskie (wsie Nowosiółki Pokropiwne i Sahryń oraz części wsi Suszów i Wasylów Pokropiwny) w powiecie bełskim, których obligatoryjnym posesorem został w 1733 r., po pożyczeniu 93.500 złp ich dziedzicowi, Karolowi Tarle, wojewodzicowi lubelskiemu i staroście stężyckiemu. Ponieważ dług ten nie został zwrócony, a później nawet wzrósł do kwoty 133.500 złp, zastaw pozostał w ręku Młodeckiego i jego sukcesorów jeszcze przez następnych 40 lat, zaś dwór nowosielski pełnił funkcję ich głównej rezydencji ${ }^{25}$. Inną ich siedzibą był dworek w Kamieniu w starostwie sandomierskim. Tamtejsze wójtostwo, uzyskane prawdopodobnie w 1730 r. z nadania królewskiego, dzierżyła potem wdowa Młodecka i jej drugi mąż Chociszewski ${ }^{26}$.

Podczaszy Młodecki obracał dużymi sumami i zwłaszcza w ostatnich latach życia uchodził za bogatego szlachcica. W jednym z dokumentów z 1729 r. chełpił się, że ma więcej pieniędzy niż jego patronowie Zamoyscy, zaś po jego śmierci pozostawiony majątek szacowano na 600.000 złp oraz 50.000 złp w gotowiźnie, nie licząc klejnotów i sreber ${ }^{27}$. Zresztą już w 1723 r. stać go było na wyasygnowanie 100.000 złp na fundację kościoła i klasztoru paulinów w Krzeszowie nad Sanem, z ustną obietnicą dalszych 50.000 złp na ukończenie budowy. Z zobowiązania tego wycofał się już po pięciu latach, gdy narodziły się jego pierwsze dzieci. Z tej przyczyny on i wdowa po nim byli przez paulinów kilkakrotnie pozywani przed lubelski Trybunał Koronny, który w latach 1735 i 1737 wydał wyroki niekorzystne dla zakonników, ponieważ zobowiązania wobec nich były tylko ustne. Ci wszakże jeszcze długo nie dawali za wygraną, ale sprawa zakończyła się ostatecznie z negatywnym dla nich skutkiem ${ }^{28}$.

Aleksander Młodecki zmarł w 1735 r., a w 1737 r. wdowa spisała regestr rzeczy pozostałych po jego śmierci ${ }^{29}$. Pierwszą jego żoną była Helena z Zachczyńskich, córka Stefana i Barbary z Komorowskich herbu Łabędź. Z nią nie dochował się potomstwa. Po śmierci Heleny w 1725 r. poślubił Konstancję (zm. ok. 1779), córkę stolnika drohickiego, Józefa Bazylego Wereszczaki z Kamienia w województwie brzesko-litewskim, oraz jego drugiej żony, Ludwiki Brygidy z Oborskich $^{30}$. Zapis wzajemnego dożywocia spisał z nią 18 kwietnia 1730 r. w grodzie lubelskim. Z tego związku doczekał się czworga dzieci, w kolejności urodzenia: córki Franciszki Teresy, syna Kajetana oraz córek Alojzy Elżbiety (Julianny) i Anny ${ }^{31}$. Po jego śmierci, już w roku następnym, przed 14 sierpnia, Konstancja powtórnie wyszła za mąż za Józefa Chociszewskiego ${ }^{32}$.

Nowy małżonek Konstancji, wedle — z pewnością nieco przesadzonych — późniejszych manifestacji pasierbów, miał być „człekiem gołym”, „nad złotych sto substancyi swojej nie mającym" "33. Wywodził się z wielkopolskiego rodu herbu Junosza, którego jedna gałąź osiadła w województwie rawskim. Był synem Marcina Chociszewskiego, podstolego nowogrodzkiego i starosty zgierskiego, oraz Marianny z Miedzwieckich vel Niedźwieckich. Jego pierwszą żoną była zmarła w ok. 1730 r. Zuzanna ze Skórzewskich, z którą miał syna Stanisława, późniejsze-

25 APL, KgH RMO, ks. 49, s. 276; APL, KgL RMO, ks. 299, k. 49; APL, KgLZ, ks. 161, k. 360v-361, 362.

${ }^{26}$ APL, KgH RMO, ks. 48, k. 530; Księgi referendarii. 1979, s. 322, nr 2318; Boniecki A. 1900-1911, t. 3, s. 15 .

27 AGAD, AZ, sygn. 1367, k. nlb (punkta z suplik gromad klucza gorajskiego); APL, KgH RMO, ks. 48, k. 529 (interrogatorium z 7 IX 1747 r. w Krasnymstawie); Orłowski R. 1959, s. 145-146.

${ }^{28}$ Encyklopedia kościelna. 1892, t. 18, s. 509-510; Zbudniewek J. 1994, s. 78-79.

29 APL, KgH RMO, ks. 51, k. 721-722v (oblata z 1764 r.).

${ }^{30}$ Kosiński A.A. 1881, t. 3, s. 555-556.

31 APL, KgH RMO, ks. 48, k. 464.

32 APL, KgL RMO, ks. 272, k. 631-632 (regestr rzeczy zabranych przez Chociszewskich podczas zajazdu na dwór w Kamieniu w dniu 14 VIII 1736 r.); APL, KgK RMO, ks. 51, k. 722-722v (wzmianka o zapisie w regestrze rzeczy po śmierci Młodeckiego). Boniecki żonie Chociszewskiego błędnie przypisuje nazwisko Wereszczyńska (Boniecki A. 1900-1911, t. 3, s. 15).

33 APL, KgH RMO, ks. 48, k. 460v. 
go dominikanina ${ }^{34}$. W bezkrólewiu w 1733 r. był sędzią kapturowym i oficjalnym posłem rodzinnej ziemi gostyńskiej na elekcję. Po roku 1737 uzyskał nadanie drobnej, dwuwioskowej tenuty długołęckiej (wsie Długołęka z folwarkiem i Niedrzaków) w województwie rawskim, zaś w 1746 r. został skarbnikiem buskim ${ }^{35}$. Kontakty ze środowiskiem szlachty województw bełskiego i lubelskiego zapewne nawiązał poprzez zawarte ok. 1720 r. małżeństwo swej siostry Anny z Franciszkiem Dzierżanowskim, łowczym liwskim i burgrabią zamojskim ${ }^{36}$. Być może to za jej pośrednictwem zawarł związek z bogatą wdową po Młodeckim. W przeciwieństwie do jej pierwszego męża, Chociszewski nie wykazywał się talentem ekonomicznym. Zawierał niekorzystne transakcje finansowo-majątkowe, przeciwko którym protestowali nie tylko jego pasierbowie, ale z czasem nawet własna żona. W manifestacji z 20 sierpnia 1747 r., przy asystencji swego brata Jana, domagała się bowiem unieważnienia „szkodliwego” mężowskiego układu z Zamoyskimi o zastaw Goraja ${ }^{37}$. Chociszewscy nie tylko marnotrawili zebraną przez zmarłego fortunę, ale nawet musieli zaciągać pożyczki, obciążając dobra „różnemi długami wielkiemi z boku od kredytorów prawnemi inwolucjami zawikłane"38. Dlatego dorośli już Kajetan Młodecki z siostrą Julianną Wydżdżyną w 1747 i 1749 r. oskarżali zwłaszcza matkę, że mężowską ,substancyję całą w wdowim stanie [...] nie tylko pożytkowała, ale i nie pamiętając na spłodzone dzieci swoje, poniekąd porozpraszała, potem na większą ruinę i zginienie tejże [...] tak znacznej i wszystkim wiadomej rodzica pozostałej fortuny [...] pozwalała”. Chcąc ratować resztki swego spadku ,protestowali i manifestowali się [...] o całość substancyi i fortuny ojczystej [...], żeby w ostatnią nie szła ruinę i do szczętu zginąć nie mogła"39.

Z drugim mężem Konstancja Werszczakówna miała jeszcze troje młodszych dzieci: synów Marcina (późniejszego podczaszego buskiego, zmarłego po 1783 r.) i Franciszka (późniejszego kanonika i kanclerza kapituły chełmskiej, zmarłego w 1802 r.) ${ }^{40}$ oraz córkę Barbarę (później żonę nieznanego z imienia Wyżyckiego $)^{41}$. Na nich skupiła swą uwagę i troskę, natomiast odsunęła starsze potomstwo z pierwszego związku. Więcej serca zachowała jeszcze dla najstarszej, dotychczas ulubionej córki Franciszki (zm. po roku 1780). W 1743 lub 1744 r. wydała ją za starościca zakroczymskiego Fabiana Młockiego, cześnika żydaczowskiego ${ }^{42}$, dając jej znaczną wyprawę w srebrze, klejnotach i innych sprzętach, aczkolwiek nie wypłacając należnego posagu. Ten, w wysokości 44.000 złp, wypłacił dopiero brat Kajetan w 1750 r., po restytucji części ojcowskiego majątku ${ }^{43}$. Sam Kajetan (zm. po 1764 r.), kanonik lwowski od 1746 r. i infułat kodeński od 1749 r., zdaje się, że był darzony przez matkę mniejszym afektem. Ze źródeł wynika, że był bity przez nią w napadzie szału nawet jako dorosły, kiedy już był księdzem i gdy stawał w obronie maltretowanej siostry ${ }^{44}$. Natomiast dla dwóch młodszych córek zaczęła się prawdziwa gehenna w relacjach z impulsywną i srogą rodzicielką. Dla najmłodszej Anny maltretowanie skończyło się wszak dość szybko, po rychłym wysłaniu do klasztoru: „z rąk macierzyńskich

34 CPAHUK, f. 49, sygn. 139, k. 1-1v (genealogia Chociszewskich); Boniecki A. 1900-1911, t. 3, s. 15.

35 Elektorowie. 1908, s. 27; Urzędnicy bełscy. 1992, nr 598.

36 Morys-Twarowski M. 2013, s. 315-316.

37 APL, KgH RMO, ks. 48, k. 489v-490v.

38 APL, KgH RMO, ks. 49, s. 18.

39 APL, KgH RMO, ks. 48, k. 460-461v (manifestacja z 19 VI 1747 r.), ks. 49, s. 18 (komplanacja z 23 I 1749 r.).

40 AAL, AKL, sygn. Rep. 60 AL 13, k. 1-2 (testament ks. Franciszka Chociszewskiego z 28 II 1799 r. w Krasnymstawie); Marczewski J. 2013, s. 120, 280-281, 776, 788, 783, 795.

41 APL, KgH RMO, ks. 51, s. 537; CPAHUK, f. 49, sygn. 139, k. 1v.

42 Po śmierci Młockiego w 1762 r. w dwa lata później Franciszka Teresa wyszła za cześnika wschowskiego Józefa Błeszyńskiego vel Błeszczyńskiego, Boniecki A. 1900-1911, t. 1, s. 284; Uruski S. 1914, t. 11, s. 156; Urzędnicy ruscy, nr 1359.

${ }^{43}$ APL, KgH RMO, ks. 49, s. 16-17, 18.

${ }^{44}$ APL, KgH RMO, ks. 48, k. 528v, ks. 49, s. 162, 229. 
kaliczona [kaleczona - W.B.], do wielebnych panien franciszkanek konwentu zamojskiego do klasztoru wypchnięta bez odzienia i wiktu, jakby sierota po niemających nic rodzicach" 45 . W klasztorze zamojskim pozostawała jeszcze w 1749 r. i zdaje się potem zeń wyszła, gdyż w 1761 r. była żoną cześnika drohickiego, Łukasza Trembińskiego z Leszczkowa ${ }^{46}$.

Główną ofiarą sadystycznych skłonności Konstancji Chociszewskiej stała się więc jej średnia córka Julianna. Najprawdopodobniej urodziła się w 1731 r., ponieważ w dokumentach z 1747 r. jest mowa o tym, że ma szesnaście lat ${ }^{47}$. Zagadkowo przedstawia się kwestia jej imienia, bowiem w pierwszych aktach nazywana była Alojzją Elżbietą ${ }^{48}$, później albo Alojzją An-

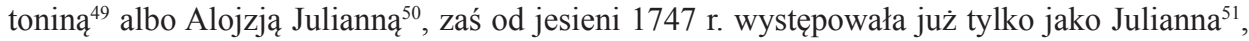
a z całą pewnością zawsze chodziło o tę samą osobę. Zresztą jej pierwotne, raczej oryginalne imię sugerowałoby, że mogła urodzić się 21 czerwca, czyli w dzień upamiętnienia niedawno kanonizowanego jezuity, św. Alojzego Gonzagi, którego kult był w tym czasie dość popularny ${ }^{52}$. Używanie nowego imienia mogło być, choć to tylko domysł, próbą zatarcia traumatycznej pamięci o nieszczęśliwym dzieciństwie i wczesnej młodości.

Została wcześnie, w wieku zaledwie czterech lat, osierocona przez ojca. Czy już wówczas była bita przez matkę? W świetle analizowanych źródeł można zakładać, że jeszcze nie. Wprawdzie Konstancja w zasadzie przez cały czas charakteryzowała się brutalnością, „przez niewypowiedzianą złość swoją, tak przyrodzoną, jako też i nabytą" ${ }^{33}$, aczkolwiek na razie swą gwałtowną naturę wyładowywała na służbie i poddanych chłopach, co w tej epoce bynajmniej nie było rzadkością, nawet w przypadku osób o zdecydowanie spokojniejszym usposobieniu. Już w 1729 r., czyli jeszcze za życia pierwszego męża, chłopi z Czarnegostoku w kluczu gorajskim w suplice skierowanej do ordynata w Zamościu skarżyli na nią o nieustanne bicie aż do krwi i zakuwanie w dyby. Na wieść o zaniesieniu supliki, kazała ona pojmać kilku z nich, „okrutnie obić aż do prawie śmierci”, oświadczając całej wsi, że ,jeszcze was lat trzy trzymać będę i choć was pozabijam, to się jm. pana ordynata o to nie boję" ${ }^{54}$. Także znacznie później, bo w styczniu 1763 r., gromada z wójtostwa podsandomierskiej wsi Kamień oskarżyła ją o zmuszanie do nadmiernych powinności, nieustanne bicie i inne krzywdy ${ }^{55}$. W wyżej wspomnianym przesłuchaniu z 1747 r. jeden ze świadków, sługa Chociszewskiej, zeznał, że sam, „wziął w pysk ze trzy tysiące razy, żem spuchł”, a inny, że jego pani „dla bicia i tłuczenia sługi żadnej utrzymać dłużej nie mogła" 56 .

Sytuacja Julianny zmieniła się na gorsze po urodzeniu przez Konstancję młodszych dzieci w drugim małżeństwie z Chociszewskim. Matka od początku Juliannę „do piastowania dzieci z teraźniejszym małżonkiem swoim spłodzonych zażywała”. Dziewczyna musiała zajmować się całą trójką, „niańczyła, z plugastwa opierała, na rękach tak w domu, jako i w kościele za matką [...] i innych publicznych miejscach bez wszelkiej rekognicyi [...] nosiła"57. Szczególnie długo

${ }^{45}$ APL, KgH RMO, ks. 48, k. 461.

${ }^{46}$ APL, KgH RMO, ks. 51, s. 195, 535-536. Spisy urzędników podlaskich nie notują takiej osoby, Urzędnicy podlascy. 1994, $\mathrm{nr}$ 386-394, s. 194.

${ }^{47}$ APL, KgH RMO, ks. 48, k. 461-461v.

${ }^{48}$ APL, KgChL RMO, ks. 78, k. 45; APL, KgH RMO, ks. 48, k. 460, 536; APL, KgLZ, ks. 161, k. 360.

${ }^{49}$ APL, KgH RMO, ks. 49, s. 18.

${ }^{50}$ APL, KgH RMO, ks. 48, k. 528v.

${ }^{51}$ APL, KgH RMO, ks. 48, k. 534, ks. 49, s. 8, 103, 552, 553, ks. 51, s. 241.

${ }^{52}$ Encyklopedia katolicka. 1985, s. 384-385.

${ }^{53}$ APL, KgH RMO, ks. 48, k. 530 (przesłuchanie świadków).

${ }^{54}$ AGAD, AZ, sygn. 1367, k. nlb.

${ }^{55}$ Księgi referendarii. 1979, s. 322, nr 2318.

${ }^{56}$ APL, KgH RMO, ks. 48, k. 532v.

${ }^{57}$ APL, KgH RMO, k. 460v-461, 529, 532. 
zajmowała się przyrodnią siostrą Barbarą, którą „wycierała, nosiła ją, a kiedy się rozpłakała, to jejm. panią Wydżdżynę teraźniejszą matka w pysk lała, aż [ta — W.B.] posoką się oblała"58. Jednocześnie matka „zaraz po śmierci ojca jej, z serca macierzyńskiego rugowawszy”, bez ustanku zatrudniała ją do wszelkich ,robót prostych [...] stanowi szlacheckiemu nieprzystojnych, do prac wiekiem niepozwalających [...], jako to do zamiatania izb, gotowania jeść, prania chust i innych jak najprościejszych i najpodlejszych obróciła robót; których że nie wystarczała, strasznie codziennie bita była" 59 . Po odejściu z domu rodzonych sióstr i brata, Julianna „w wielkiej mizeryi trzymana była”. Wedle relacji ,sukni bławatnej, nawet bielizny przystojnej z tak wielkiej substancyi swojej nigdy mieć nie mogła, ale jakby najostatniejsza służebnica odzienie nosić musiała [...], najmniejszego kawałka jedwabnego nie schodziła”. Chodziła boso bądź w prymitywnych łapciach, spała w swojej izbie, ale na podłodze „na niedźwiedziu” obok łóżka, „nie znając nigdy pościeli, tak w zimie, jako i w lecie [...]. Z czeladzią i praczkami w kuchni albo piekarni potrawy [...] zdrowiu szkodzące, wpół ze łzami one mieszając, jadać musiała" ${ }^{60}$. Przy takim traktowaniu nawet jeden z zeznających sług twierdził: „zrazu, jak przystałem do pana [Chociszewskiego - W.B.], rozumiałem, że to zwykła dziewczyna służebna"61.

Ciekawe było silne artykułowanie braku odpowiedniego, ,szlacheckiemu stanowi przystojnego" wykształcenia starszych dzieci. W piętnastopunktowej liście zarzutów ten umieszczono zaraz po pierwszym - o zagarnięciu i marnotrawieniu ojczystego majątku. Konstancji wytykano, że po śmierci pierwszego męża ,żadnej dzieciom zupełnej nie dawała edukacyi”. Zeznania świadków w zasadzie to potwierdzały, jakkolwiek podkreślano, że dotyczyło to „osobliwie jejm. pani ad praesens [Julianny - W.B.] Wyżdżyny, w stanie panieńskim zostającej”, która w przeciwieństwie do pozostałego rodzeństwa „,nauki [...] żadnej nie miała, bo nie tak [sic] u matki była"'62.

Najgorsze było codzienne bezlitosne bicie córki przez matkę: „od rana do wieczora nieprzestannemi policzkami traktowana, rózgami, kańczugami bita. I co wielmożnej matce napadło, czyli to kij czyli wałek, polano, tym kaliczona z wielkim niebezpieczeństwem zdrowia i życia, i daleko bardziej niż jaka niewolnica męczona bywała”. Według innej relacji: „taż jejm. pani Chociszewska matka, tak w domu jako i w gościnie, tudzież po drogach, noclegach i popasach, nielitościwie bijała rózgami, nahajami, pokrzywami, głog[i]em, postronkami, kijami grubemi na zabój. Iż nie tylko w domu, ale po żydowskich domach krew lała [się] strumieniami, na podziw ludzki patrzących się" ${ }^{63}$. Świadek dodawał, że „to też bywało, że jako ludzi innych, tak też panią podstolinę teraźniejszą, porwawszy za łeb, o ścianę głową tłukła, kułakami w nos bijała do krwi”"64. Ostatnie rany głowy, stwierdzone podczas obdukcji, zostały zadane cynowym kałamarzem i „młotkiem czyli obuchem”" ${ }^{6}$. Dwóch zeznających twierdziło, że Konstancja w największą furię wpadała, gdy była pijana (,,i to sam widziałem, że razy pięć — sześć gorzałkę pije na dzień"), choć pozostali świadczyli, iż nigdy swej pani nie widzieli pijanej, a biła „dogadzając swojej cholerze”66. Gdy już osłabła z wysiłku, kazała tłuc sługom, w czym nie-

58 APL, KgH RMO, k. 532.

59 APL, KgH RMO, k. 461 (manifestacja), k. 529-532v (zeznania czterech świadków).

${ }^{60}$ APL, KgH RMO, k. 461, 529v-532, ks. 49, s. 18 (komplanacja, świadectwo brata i wuja).

${ }^{61}$ APL, KgH RMO, k. 531v.

${ }^{62}$ APL, KgH RMO, k. 529, 531v, 532-532v. Później Julianna zdaje się nadrobiła te podstawowe braki w wykształceniu. O tym mógłby świadczyć staranny krój jej własnoręcznych podpisów pod manifestacją z $1775 \mathrm{r}$. i pod sporządzonym przez nią regestrem rzeczy po śmierci drugiego męża - Antoniego Dłużewskiego z 1778 r. (APL, KgChL RMO, ks. 82, k. 45, 526), a także fakt podarowania swych kilku książek córce Franciszce, uwzględniony w regestrze wyprawy z 1774 r. (APL, KgCh RMO, ks. 172, k. 133v).

${ }^{63}$ APL, KgH RMO, ks. 48, k. 461, 529.

${ }^{64}$ APL, KgH RMO, k. 532a (karta pominięta w paginacji).

${ }^{65}$ APL, KgH RMO, k. 532a-532av.

${ }^{66}$ APL, KgH RMO, k. 531-533. 
zwykłą bezwzględnością wyróżniał się niejaki Witwicki, zapewne ekonom, siejący przerażenie także wśród chłopów ${ }^{67}$. Bezwolność rodziny i bezkarność tylko rozzuchwalały matkę w okrucieństwie wobec córki. Doszło do tego, ,iż jejm. pani Chociszewska matka, przy tak strasznym biciu i kaliczeniu córki swojej [...], nieraz mawiała, że «cię bestio zabiję, nie doczekasz pójść za mąż, ani fortuny ojcowskiej partycypować»" ${ }^{68}$. Przy dworze w Nowosiółkach trzymała Juliannę w komórce: „w męczarni [...] po dni kilka zamykała i głodem morzyła, chcąc koniecznie zamorzyć. Do którego miejsca poddani z kompasyi po kawałku chleba rzucali albo też jm. ksiądz kanonik lwowski, brat [...], jeżeli w domu natenczas był. O czym jak się dowiedziała jejm. pani Chociszewska, ludzi za to kaliczyła"69.

Wszystko wskazuje, że mąż sadystycznej Konstancji, Józef Chociszewski, nie brał udziału w maltretowaniu pasierbicy. W wielu późniejszych manifestacjach i pozwach pasierbowie oskarżali go o zawłaszczenie ojcowskiego majątku, o jego rujnowanie, aczkolwiek nigdy o bicie i nieludzkie traktowanie. Atoli z nieznanych powodów zachowywał bierność ${ }^{70}$ i tylko sporadycznie próbował bezskutecznie powstrzymywać katowanie pasierbicy Julianny. O jednym takim przypadku opowiedział jeden ze świadków stwierdzając, że Konstancja ,jejm. panią podstolinę teraźniejszą [czyli Juliannę - W.B.], obróciwszy miotłę grubszym trzonkiem, w kącie w łeb ściubała kilkadziesiąt razy. Natenczas na krzyk przyszedł jm. pan Chociszewski od stajni. Perswadował, odbraniał, ale jejm. pani Chociszewska niepohamowana była. Aż w tym sami między sobą ichm. Chociszewscy zróżnili się i samego jegomości w tym rozbranianiu w gębę uderzyła". Innym razem tylko beznamiętnie przyglądał się ekscesom żony, kiedy zimą Julianna uciekała przed biciem „,boso, bez pończoch, drżąc na mrozie, tak iż sam jm. pan starosta [długołęcki - W.B.] mówił: «nie wiem jak rogata dusza w tej pannie, że nie umrze»" "71.

W bezsilnej rozpaczy, śladem młodszej siostry Anny, Julianna „męczeństwa unikając, a bardziej przestrzegając życia swego i zdrowia [...] choć na takąż mizeryję, byle ze zdrowiem rezolwując się, ustawicznie do klasztoru wypraszała się i przez rodzonych wujów swoich [Bogusława i Jana Wereszczaków - W.B.] instancjonowała, a nie puszczona”. Wobec tego w desperacji, „bez pozwolenia matki i wiadomości jej” uciekła do klasztoru brygidek w Lublinie, mając „tam ciotkę swoją ${ }^{72} \mathrm{w}$ zakonie świętym”. Odnaleziona przez matkę, ,stamtąd gwałtownie wzięta, potem ciężkie plagi i nieraz odniosła" ${ }^{\prime}$. Innym razem, już po przeniesieniu z bełskich Nowosiółek do sandomierskiego Kamienia, „w mrozy i zimę tęgą, goło i boso uciekając, mało się życia nie pozbawiła”, przebyła pieszo trzydzieści mil (przeszło 200 kilometrów!) i schroniła się w dworze swej starszej siostry, Franciszki Młockiej w Żulinie. Decyzja ta nie była zupełnie przemyślana, z uwagi na nieprzychylną ku niej postawę siostry, która już wcześniej kilka razy uczestniczyła w maltretowaniu Julianny przez matkę ${ }^{74}$. Franciszka, wbrew swemu mężowi Fabianowi, natychmiast zawiadomiła matkę o celu ucieczki swej młodszej siostry. W efekcie odbyła się swoista „egzekucja” tej ostatniej, bowiem wedle relacji: „po którą, dowiedziawszy się, matka przyjechała do Żulina [...]. Tam zastawszy jejm. panią Wydżdżynę teraźniejszą, zamknąwszy się z nią w izbie, drzwi popodpierawszy, do koszuli rozebrać kazała i onę nahajami więcej godziny pachołkom bić w czas mroźny i zimny kazała na zabój. Pewnie by tam duszę

${ }^{67}$ APL, KgH RMO, k. 530, 532v.

${ }^{68}$ APL, KgH RMO, k. 529-529v, 532-532v.

${ }^{69}$ APL, KgH RMO, k. 530v.

${ }^{70}$ Można jedynie snuć przypuszczenie, iż mogło chodzić o ekonomiczne uzależnienie od zamożnej żony, bądź po prostu nie mógł sobie poradzić z wybuchowym charakterem małżonki.

71 APL, KgH RMO, ks. 48, k. 532a.

72 Nie wiadomo o kogo chodzi. W spisie brygidek lubelskich nie ma żadnej zakonnicy o nazwisku Młodecka lub Wereszczakówna (zob. Metryka brygidek. 2011). Niewykluczone, że tą „ciotką” była jakaś dalsza krewna o jeszcze innym nazwisku.

${ }^{73}$ APL, KgH RMO, ks. 48, k. 461-461v.

${ }^{74}$ APL, KgH RMO, k. 530, 532a. 
wyzionęła, gdyby jm. ksiądz Młodecki, kanonik lwowski, z jm. panem Młockim drzwi nie wystawili z ludźmi swemi i nie salwowali siostry swojej. Którego jm. księdza kanonika jejm. pani Chociszewska matka za tę kompasyję nad siostrą, że drzwi wystawił i dalej jej bić nie dał, wyrwawszy od pachołka kańczug, razy go kilka [...] uderzyła. Po którym to tak strasznym biciu, zaraz nazajutrz dużo zbitą i zranioną teraźniejszą jejm. panią Wydżdżynę jejm. pani matka wziąwszy, nie dawszy żadnego opatrzenia razom pobitym, z Żulina do domu mil trzydzieści $\mathrm{z}$ nią pojechała. W drodze z pobitej futro zdarła, która jedyną mocą Pana Boga była salwowana, kiedy nieraz w drodze od ciężkich razów i zimna nieznośnego mdlała"75.

Julianna kilkakrotnie na próżno prosiła niektórych z życzliwej sobie służby i chłopów folwarcznych o pomoc w następnej ucieczce. Odmawiali ze strachu przed zemstą Chociszewskiej. Nie spełniły się także obietnice wujów Bogusława i Jana Wereszczaków, którzy ,ją od matki mieli wziąć i u siebie lokować”. W końcu ,gdy widziała coraz większą mizeryję życia swego, nieraz zamyślała się topić i śmierci [sobie - W.B.] zadawać"76. Wiosną 1747 r. nadarzyła się wreszcie najlepsza okazja do tym razem udanej ucieczki „od matki z niewolniczej i nader przykrej opieki" "77. Na kondescensję do Kamienia zjechało kilku szlachciców z czeladzią, $\mathrm{w}$ tym niewątpliwie orientujący się w dramatycznej sytuacji Julianny dawni sąsiedzi z województwa bełskiego — podstoli bełski Michał Józef Wydżga i niewymieniony z imienia Ołtarzewski, najprawdopodobniej Józef Dominik, późniejszy łowczy horodelski. O szczegółach tej ucieczki wiadomo dość sporo, jako że stanowiła ona główny przedmiot dociekań podczas tylekroć już cytowanych przesłuchań przed konsystorzem chełmskim. Udowodnienie faktu i przyczyn ucieczki było wszak podstawą linii obrony przed zarzutem o porwanie panny i zmuszenie jej gwałtem do zaślubin z Wydżgą, o co ten oskarżany był przez matkę Julianny. Zarówno dziewczyna, jak i pozostali świadkowie zaprzeczyli porwaniu i zgodnie poświadczyli „,dobrowolną" ucieczkę, z detalami opisując jej motywy i przebieg. Skądinąd wiemy, że zeznający słudzy Chociszewskiej mieli być przez nią zmuszani do krzywoprzysięstwa: ,prawda, iż jejm. nasza, wyganiając nas do tego świadectwa, tak nam kazała zeznawać, iż ona [czyli Julianna - W.B.] gwałtu wołała i hałas się stał, kiedy panna uchodziła. I kazała nam to na swoją duszę przysięgać”. Ci, którzy nie zasłaniali się niewiedzą lub niepamięcią, kolejno tłumaczyli niezaspokojenie żądań swej pani argumentem: „bo jedną mam duszę”78. Skutkiem tego zarówno dekret konsystorski z grudnia 1747 r., jak i o rok późniejszy dekret lubelskiego Trybunału Koronnego, uniewinniły Wydżgę i oddaliły oskarżenie Chociszewskiej ${ }^{79}$.

Powróćmy jednak do opisu tej ucieczki i jej następstw, jako upragnionego ostatecznego wyzwolenia z nieludzkiego traktowania przez matkę. W kwietniu 1747 r. Wydżga przyjechał na zjazd sądowy w Kamieniu, z racji swego urzędu pisarza grodzkiego horodelskiego będąc wraz z innymi zaproszonym przez Chociszewskich i przebywał tam trzy tygodnie. Wprawdzie sam odżegnywał się od jakiegokolwiek udziału w poczynaniach panny Młodeckiej, twierdząc też, że nie uczestniczyli w tym jego słudzy i że o sprawie dowiedział się dopiero po tygodniu ${ }^{80}$,

75 APL, KgH RMO, k. 529v, 531v-532v. W biciu Julianny w Żulinie brał udział jeden z późniejszych świadków w przesłuchaniu przed konsystorzem.

${ }^{76}$ APL, KgH RMO, k. 529v, 531-532v.

77 APL, KgH RMO, ks. 49, s. 18 (relacja brata Kajetana).

78 APL, KgH RMO, ks. 48, k. 533.

79 APL, KgH RMO, k. 533v-535v (oblata dekretu konsystorza chełmskiego z 11 XII 1747 r. w Krasnymstawie), k. 536-537 (oblata dekretu trybunalskiego z 1 X 1748 r.); AAL AKL, sygn. Rep 60 A 128, k. 374-376 (dekret sądu konsystorskiego z 11 XII 1747 r.). Dekret konsystorski podpisali: ks. Jan Aleksander Trembiński, proboszcz katedralny i oficjał generalny chełmski, kanonik lwowski, archidiakon kolegiaty lubelskiej, proboszcz wilkołaski i rycki, oraz ks. Michał Duńczewski, kanonik chełmski i zamojski, notariusz apostolski i rektor Akademii Zamojskiej. Natomiast dekret Trybunału jak zwykle nie zawiera nazwisk sądzących deputatów, a jedynie podpis sędziego ziemskiego lubelskiego, Dominika Stanisława Sylwestra Stoińskiego, zob.: Deputaci. 2017, s. 17-18.

${ }^{80}$ APL, KgH RMO, ks. 48, k. 530-539v. 
jednak nieco inaczej przedstawiają to zeznania dwóch świadków. Oświadczyli oni, że widzieli, jak w tydzień po przybyciu „w kościele w Kamieniu ze trzy pacierze dyskutowali ze sobą jm. pan Wydżga z jejm. panią teraźniejszą Wydżdżyną". Kilka dni później, Julianna wyszła nocą skrycie z dworu w towarzystwie służebnej. W sadzie czekali na nie dwaj słudzy pisarza horodelskiego. Szybko, ale zupełnie spokojnie i bez hałasu (co podkreślali świadkowie), zaprowadzili ją do stojącego za sadem, gotowego do drogi powozu Ołtarzewskiego ,i tejże nocy pojechali z mil, jak powiadają, dwanaście”. Natomiast w tym czasie ,jm. pan Wydżga na łóżku leżał i za próg nie wychodził”. Podobnie oświadczyła sama Młodecka: „na kondescensyi prosiłam się ludzi [...], aby mnie wywieźli. Sama tedy poszłam dobrowolnie z ludźmi jm. pana Wydżgi, którzy mnie i służbistę [służącą — W.B.] jejm. matki mojej wyprowadzili do pojazdu już gotowego" "81. Po dwóch dniach przyjechała do województwa bełskiego. Znalazła schronienie u miecznikowej grabowieckiej, Franciszki z Ciesielskich Rosochackiej, zapewne w Waniowie, co z pewnością też zostało z góry umówione. Tam przebywała dwa tygodnie. W międzyczasie zjawił się powracający z sądów Wydżga i według słów Julianny: „traktował z jejm. panią Rosochacką o przyjaźń moją, na co ja dobrowolnie pozwoliłam". Następnie w sobotę przed Zielonymi Świątkami wraz z Rosochackimi zjechała do dworu Wydżgi w Raciborowicach i już następnego dnia, to jest 21 maja 1747 r., wzięła z nim ślub w pobliskim kościele w Moniaty$\mathrm{czach}^{82}$. Ślubu udzielił tamtejszy proboszcz, ks. Antoni Bartłomiej Tuszowski, kanonik chełmski, w obecności Franciszki Rosochackiej i jej męża Wojciecha, miecznika grabowieckiego, a także niewymienionych $\mathrm{z}$ imion pisarzowiczów Jeziorkowskich oraz skoligaconego z Wydżgami starosty pełczyńskiego, Franciszka Ksawerego Świeżawskiego ${ }^{83}$. Zastosowany tu pośpiech z pewnością był podyktowany potrzebą jak najskuteczniejszego przeciwdziałania spodziewanym staraniom Chociszewskiej o uniemożliwienie zawarcia przez córkę małżeństwa i o jej powrót do domu. A łatwo można się domyślić, co tam by na nią czekało. Jak słuszne były te obawy, pokazały wspomniane powyżej pozwy złożone przez matkę przed sąd konsystorski chełmski i Trybunał Koronny ${ }^{84}$.

Konstancja Chociszewska obawiała się przede wszystkim roszczeń córki Julianny Wydżdżyny oraz syna Kajetana w kwestii rewindykacji z jej rąk ojcowskiego majątku, a właściwie tego, co z niego pozostało po latach niegospodarności i systematycznego zadłużania. Walka z Chociszewską o zwrot dóbr była trudna, bo w istocie za nią stało prawo. Aleksander Młodecki za swojego życia, „ze zbytniego afektu”, jak to określili potomkowie w jednej z manifestacji, poczynił bowiem zapisy dożywocia dla żony Konstancji na większości swego majątku ${ }^{85}$, a ten nie podlegający zapisom został bezprawnie „rozproszony”, bądź obciążony dużymi sumami zastawnymi i „zawikłaniami” prawnymi. Pierwszy mąż wyjednał też dla niej ius communicativum na swym wójtostwie Kamień w ekonomii sandomierskiej. Tam to Chociszewscy z rodziną przenieśli się w 1745 lub 1746 r., po zajęciu Nowosiółek Pokropiwnych w posesję obligatoryjną przez zastawnika, kanonika gnieźnieńskiego Józefa Antoniego Łaszcza, a następnie przez braci Ołtarzewskich ${ }^{86}$. Michał Wydżga, od tego czasu niewątpliwie inspirujący i kierujący działaniami żony i szwagra, najpierw oczywiście zadbał o własny interes. Natychmiast po ślubie z Julianną porozumiał się z jej bratem Kajetanem oraz wujem Bogusławem Wereszczaką i 20 czerwca 1747 r.

${ }^{81}$ APL, KgH RMO, k. 532-532v, 532av.

82 APL, KgH RMO, k. 532av.

${ }^{83}$ APL, KgH RMO, k. 532v, 535 (dekret konsystorski).

${ }^{84}$ Może też lękano się zapisu prawa: ,że gdyby nawet białogłowa zeznawała, iż rapt z jej woli zaszedł, przecież raptor kary zasłużonej ujść nie może”, Ostrowski T. 1787, s. 360. O tym też: Bezzubik E. 1999, s. 68, 71.

${ }^{85}$ APL, KgH RMO, ks. 48, k. 460v, ks. 51, k. 722-722v (zapis wzajemnego dożywocia z 18 IV 1730 r.).

${ }^{86}$ APL, KgH RMO, ks. 49, s. 9-10; APL, KgLZ, ks. 161, k. 362. W dniu 28 VI 1748 r. Konstancja Wereszczakówna uzyskała ius communicativum na drugiego męża Józefa Chociszewskiego, AGAD, Sig., sygn. 28, s. 70 . 
w Żółkwi spisał z nimi intercyzę ślubną. Kajetan Młodecki, określający się w niej ,jedynym prawnym sukcesorem dóbr ojczystych", zobowiązał się do dania siostrze posagu w wysokości 44.000 złp, płatnego do święta Trzech Króli 1750 r. Miał też zadbać o wyprawę dla siostry, gdyż ta z oczywistych względów „najmniejszej wyprawy na palec zawinąć od matki swojej nie wzięła [...], ani też najmniejszego klejnocika i sukienki żadnej”. To jednakże miało dojść do skutku dopiero „za dojściem i dźwignięciem z rąk wielm. państwa Chociszewskich zostającej fortuny" "87, dlatego Młodecki i Wydżga jednocześnie zawarli komplanację, ustalającą warunki współpracy w odzyskaniu „substancyi ojczystej [...] z nieprawego dożywocia” matki. Biorący na siebie główny ciężar wysiłków w tej materii, jako doświadczony i bieglejszy w prawie Wydżga miał poza posagiem uzyskać dodatkową sumę $6.000 \mathrm{złp} \mathrm{,za} \mathrm{fatygę} \mathrm{i} \mathrm{zobopólne} \mathrm{około} \mathrm{substancyi} \mathrm{oj-}$

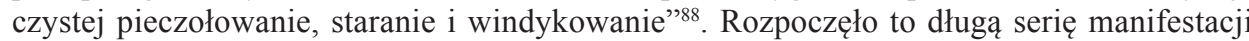
i pozwów w latach 1747-1749 przeciwko Konstancji Chociszewskiej i jej mężowi. Sprawa dwukrotnie dotarła też przed lubelski Trybunał Koronny, jakkolwiek zawarta tam w 1748 r. komplanacja nie została przez matkę ,uspokojona" ${ }^{89}$. Wreszcie wiosną 1750 r. Kajetan Młodecki odzyskał od matki część majątku i wypłacił siostrze zaległy posag wraz z umówioną sumą kosztów procesowych, łącznie 50.000 złp. Wydżga w czerwcu tego roku kwitował odbiór pieniędzy ${ }^{90}$ i odtąd stracił zainteresowanie dalszymi zabiegami o rewindykację pozostałych jeszcze w rękach teściowej dóbr nowosielskich. Jego nazwisko już nie pojawia się w aktach sądowych przeciwko Chociszewskim, a sprawę kontynuuje tylko jego szwagier, który jednocześnie w manifestacjach zarzuca Wydżdze „wyrzeczenie się starań”. Po 1752 r. także i on na długi czas rezygnuje z prób wyrugowania matki z „okupowanej” ojcowizny ${ }^{91}$, by jeszcze po raz ostatni powrócić do tego w lutym 1764 r., zaraz po śmierci ojczyma ${ }^{92}$. Prawdopodobnie sam zmarł wkrótce potem, gdyż w następnych latach już nie pojawiał się w źródłach.

Po roku $1750 \mathrm{w}$ aktach nieczęsto znajdujemy wzmianki również o Juliannie z Młodeckich Wydżdżynej, aż do momentu śmierci jej męża. Wraz z nim 20 stycznia 1755 r. w grodzie horodelskim zeznała zapis wzajemnego dożywocia, zaś w 1759 r. mąż uzyskał dla niej ius communicativum na jednowioskowej tenucie Krasne w powiecie chełmskim, niewiele wcześniej scedowanej mu przez podczaszego chełmskiego Stanisława Siłę Nowickiego ${ }^{93}$. W 1763 r. oboje przenieśli się z Raciborowic do dworu w Kopyłowie w starostwie hrubieszowskim. Wieś tę oraz sąsiednie Szpikłosy vel Szpikołosy Michał Józef Wydżga przejął w zastaw za 100.000 złp od Franciszka Salezego Potockiego, wojewody kijowskiego i starosty hrubieszowskiego ${ }^{94}$. Mąż Julianny zmarł w marcu 1765 r., a 3 czerwca tego roku wdowa w Kopyłowie spisała regestr rzeczy po jego śmierci ${ }^{95}$. Ze związku z Wydżgą urodziło się troje dzieci — córka Franciszka oraz synowie Walerian i Florian, w chwili zgonu ojca określani jako jeszcze małoletni. W 1770 r. już powtórnie zamężna Julianna wydała córkę za skarbnika chełmskiego, Krzysztofa Dłużew-

87 APL, KgH RMO, ks. 49, s. 17-19.

88 APL, KgH RMO, s. 14-17 (komplanacja z 20 VI 1747 r. w Żółkwi, oblata z 23 I 1749 r.).

89 APL, KgH RMO, ks. 48, k. 463v-464v, 466v-467, 717v-518, ks. 49, s. 8-9, 9-10, 25-26, 103-112, 162, 228-229.

90 APL, KgH RMO, ks. 51, s. 1044-1045 (kwitacja z 25 VI 1750 r., oblata z 1765 r.).

91 APL, KgH RMO, ks. 49, s. 276-277, 552, 928.

92 APL, KgH RMO, ks. 51, s. 610-614. Józef Chociszewski zmarł w styczniu 1764 r., Urzędnicy bełscy. 1992, nr 598, 600; APL, KgChL RMO, ks. 70, k. 753-754 (regestr rzeczy po jego śmierci, z 1767 r.).

93 AGAD, Sig., sygn. 29, s. 138, 154 (konsensy król. z 18 V i 5 VII 1759 r.); BN, Zb. Czołow., sygn. 5569, t. 4, s. 335 (Notaty do genealogii różnych rodzin na lit. S-Z, kontrakty małżeńskie).

${ }^{4}$ APL, KgH RMO, ks. 51, s. 1217-1218. Wsie te już wcześniej, od 1704 r., były w zastawie u jego pierwszego teścia, podczaszego podolskiego, Jana Antoniego Grzymały Kamodzińskiego, APL, KgH RMO, ks. 41, S. 1033 .

95 APL, KgH RMO, ks. 51, s. 536-537, 988-991 (regestr rzeczy z 3 VI 1765 r. w Kopyłowie). 
skiego, bogato ją wyposażając. Ta jednak zmarła młodo w 1774 r. ${ }^{96}$, najprawdopodobniej bezpotomnie. Wcześniej, bo w 1769 r., matka formalnie scedowała tenutę Krasne na starszego syna Waleriana, jednak z jakichś względów zmieniła zdanie i mimo powtórnego przekazania w kwietniu 1789 r., nadal trzymała królewszczyznę jeszcze w sierpniu 1791 r. ${ }^{97}$

Po śmierci męża Michała Józefa, wdowa Julianna w latach 1765-1766 wdała się w spór o spadek ze swymi pasierbami, pisarzem ziemskim buskim Leonem (Leonardem) Kazimierzem i łowczym horodelskim Pawłem Janem, synami Wydżgi z pierwszego małżeństwa z Domicellą Katarzyną z Kamodzińskich, podczaszanką podolską. O ile bez walki oddała spadłe im po matce dobra raciborowickie i nieledewskie na pograniczu ziemi chełmskiej i województwa bełskiego, to - ostatecznie bezskutecznie — próbowała się utrzymać przy posesji połowy Telatyna w powiecie bełskim oraz zastawnych wsi Kopyłów i Szpikłosy koło Hrubieszowa. Po podwójnej intromisji (jej i pasierbów) do zastawu w starostwie hrubieszowskim w 1765 i 1766 r. oraz procesach sądowych zrezygnowała z niego w 1769 r. Natomiast tymczasowo udało się jej zatrzymać Telatyn, na którym miała zapisane swe sumy posagowe, ale i on w nieznanych bliżej okolicznościach jeszcze przed jej śmiercią został przejęty nie przez rodzonych synów, lecz przez pasierbów ${ }^{98}$.

$\mathrm{Z}$ nieco lepszym skutkiem stoczyła batalię o majątek z pasierbami w drugim małżeństwie. Jej drugim małżonkiem był wojski krasnostawski, Antoni Dłużewski herbu Pobóg, poślubiony przez nią w Wielkanoc (30 marca) 1766 r. Syn chorążego chełmskiego Franciszka Idziego, odziedziczył po nim ćwierć dóbr uhruskich (wsie Ukrusk, Wola Uhruska i Mszanka) w ziemi

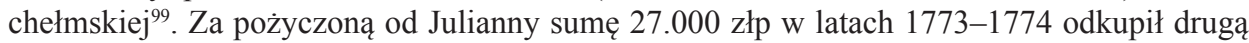
ćwiartkę tych wsi od swego młodszego brata Tadeusza. W dniu 6 stycznia 1778 r. w Uhrusku spisał testament i zaraz potem zmarł, gdyż w sześć dni później już był wymieniany jako olim. Z małżeństwa z Julianną Młodecką pozostawił czwórkę małoletnich dzieci: Franciszka, Barbarę, Katarzynę i Wiktorię, z których najstarszy Franciszek urodził się w 1771 r. ${ }^{100}$

Antoni Dłużewski, od 1773 r. łowczy krasnostawski, miał jeszcze dwoje starszych dzieci z pierwszego małżeństwa z Dominiką z Piotrowiczów, primo voto Wolbekową, podkomorzyną mozyrską: syna Feliksa i córkę Annę, żonę najpierw podczaszego rawskiego Wawrzyńca Chmielowskiego, z którym rozwiodła się w 1779 r., a następnie cześnikowicza latyczowskiego, Franciszka Leonarda Krajewskiego ${ }^{101}$. Zapewne relacje Feliksa z macochą jeszcze za życia

${ }^{96}$ APL, KgCh RMO, ks. 169, k. 112v-113v, 289-289v (regestr wyprawy z 1770 r.), ks. 172, k. 132v-133v (regestr wyprawy po śmierci Franciszki, z 24 III 1774 r. w Chylinie); APL, KgChL RMO, ks. 77, k. 613-613v (ten sam regestr).

${ }^{97}$ AGAD, Kanclerskie, sygn. 47, s. 190-191 (konsens na cesję z 22 XI 1769 r.); APL, KgH RMO, ks. 51, s. 1018; APL, KgChL RMO, ks. 105, k. 44-44v (cesja z 27 IV 1789 r. w Woli Uhruskiej); APL, KgCh RMO, ks. 191, k. 344 (jurament podatkowy Julianny z 7 X 1789 r.); Summariusz królewszczyzn. 1862, s. 27; Lipiński S. 2013, s. 323-324.

98 APL, KgH RMO, ks. 48, k. 422-422v (regestr rzeczy po śmierci Domicelli z Kamodzińskich z 1747 r.), ks. 51, s. 758 (intromisja Julianny z 6 IV 1765 r.), 1019-1020 (zapis sum posagowych), 1106-1107, 1109-1110, 1191 (intromisja pasierbów z 2 IV 1766 r.), 1217-1218 (intromisja pasierbów), 1229-1230; LNNBUL, f. 141, sygn. 2429/III (Wykaz właścicieli dóbr ziemskich w Galicji z ok. 1780 r.), s. 1405; Summariusz królewszczyzn. 1862, s. 29.

99 APL, KgH RMO, ks. 51, s. 1191, 1217. Druga połowa dóbr uhruskich należała do kasztelana wołyńskiego Michała Jana Nepomucena Ledóchowskiego, sukcesora po swej babce Zuzannie z Podoskich, która była siostrą Barbary, babki Antoniego Dłużewskiego, Bondyra W. 2003, s. 16-17.

100 APL, KgCh RMO, ks. 172, k. 178v-180v (podział majątku ruchomego pomiędzy braćmi Dłużewskimi w 1774 r.), 325v (taryfa ziemi chełmskiej z 1774 r.), ks. 175, k. 5-5v (intromisja Julianny Dłużewskiej do dóbr uhruskich z 12 I 1776 r.), 40v, 41-42v (testament Antoniego Dłużewskiego z 6 I 1778 r. w Uhrusku); APL, KgChL RMO, ks. 82, k. 394, 524-526 (regestr rzeczy po śmierci A. Dłużewskiego z 7 III 1778 r. w Uhrusku, spisany przez wdowę).

101 APL, KgCh RMO, ks. 191, k. 389-389v, 1025. Jest zamieszanie w danych o starszych dzieciach łowczego krasnostawskiego Antoniego Dłużewskiego. On sam w testamencie wymienia tylko Feliksa i Annę Chmie- 
Antoniego były nienajlepsze, skoro ten w testamencie usilnie uprasza syna o zgodę oraz opiekę nad małoletnim przyrodnim rodzeństwem i jego matką. Konflikt między nimi z całą mocą zaognił się po zgonie testatora. Już w kilka dni po tym fakcie Julianna dokonała intromisji do całości dóbr mężowskich, a następnego dnia pasierb, tytułujący się wówczas namiestnikiem wojsk Kawalerii Narodowej, w imieniu swoim i siostry domagał się zwrotu zawłaszczonych przez macochę rzeczy i sum pieniężnych, należnych im po zmarłej matce Dominice. Manifestował też o nieważności wszelkich obecnych i przyszłych transakcji na dobrach ojcowskich. Wkrótce sami dokonali intromisji do całych dóbr uhruskich, przeciwko czemu z kolei protestowała Julianna. Argumentowała to nie tylko prawem dożywocia i „prawami Boskimi i naturalnymi” swych dzieci, ale także zapisem sum pożyczonych mężowi, zabezpieczonych na tych dobrach. Po rocznych sporach odstąpiła pasierbom połowę majątku ruchomego po ich ojcu oraz wieś Mszankę i ćwierć Uhruska, z warunkiem dopuszczenia do nich swych rodzonych dzieci, po uzyskaniu przez nich lat sprawnych. Sobie pozostawiła tylko dożywocie na ćwierci Uhruska oraz połowie Woli Uhruskiej, gdzie odtąd rezydowała w tamtejszym dworku ${ }^{102}$.

W maju 1789 r. była obecna na zjeździe sądowym na gruncie w Uhrusku, rozgraniczającym części Dłużewskich i Ledóchowskich oraz ustanawiającym posesje zastawne na dobrach tych ostatnich ${ }^{103}$. Zaraz potem toczyła spór graniczny z proboszczem uhruskim, ks. Michałem Alojzym Byliną, kanonikiem inflanckim. Ten w manifestacji z 27 maja 1789 r. zarzucał jej uzurpowanie praw do sąsiadujących łąk plebańskich, darowanych jeszcze w 1690 r. przez sukcesorów podkomorzego różańskiego Mikołaja Podoskiego i jego żony Teresy z Krzywczyckich. Proboszcz oskarża Juliannę Dłużewską, że uwięziła i trzymała w dybach wypasających bydło chłopów plebańskich, a do samego bydła kazała służbie strzelać ${ }^{104}$. Najprawdopodobniej we wrześniu (pomiędzy 29 sierpnia a 7 października) tego samego roku, w wieku 58 lat Julianna po raz trzeci wyszła za mąż za wicesgerenta grodzkiego chełmskiego, Antoniego Dzierżanowskiego, młodszego od niej aż o 18 lat. Kolejny małżonek wywodził się z niezamożnej szlachty mazowieckiej herbu Grzymała i był synem Jakuba oraz Franciszki z Rudkowskich vel Rutkowskich. Od co najmniej 1780 r. pełnił funkcję plenipotenta swej przyszłej żony, przed 26 lutego 1789 r. został wicesgerentem chełmskim, zaś przed 24 lutego 1790 r. uzyskał nominację na podczaszego horodelskiego ${ }^{105}$. Oboje Dzierżanowscy w czerwcu 1796 r. pozywali szlachcica Lisieckiego o doprowadzenie do zniszczenia dworu uhruskiego podczas jego trzyletniej posesji dzierżawnej, zaś w 1799 r. byli wymieniani w akcie wizytacji parafii uhruskiej ${ }^{106}$. Na tym ostatnim roku kończą się wiadomości źródłowe o Juliannie z Młodeckich Dzierżanowskiej. Prawdopodobnie wówczas dokonała żywota w dość sędziwym dla kobiety w owych czasach wieku 68 lat. Trzeci mąż przeżył ją i zdaje

lowską. Natomiast A. Boniecki (Boniecki A. 1900-1911, t. 3, s. 169, t. 4, s. 296) jako jego pierwszą żonę podaje Ewę z Cieciszewskich, zmarłą przed 1754 r. Z ich związku narodził się syn Hieronim. Informację tę można by uznać za błąd heraldyka, gdyby nie fakt, iż w 1753 r. Dłużewski za 1.500 złp zakupił połowę tzw. pałacu Parysów w Lublinie od szwagra, Antoniego Kolumny Cieciszewskiego, nazwanego wówczas starostą mielnickim, choć faktycznie był synem starościca, APL, KgL RMO, ks. 325, k. 550-550v (intromisja), 535v-536v (kontrakt z 16 VIII 1753 r. w Chełmie). Dominiki z Piotrowiczów nie wymienia żaden z herbarzy.

102 APL, KgCh RMO, ks. 175, k. 5-5v (intromisja Julianny z 12 I 1778 r.), 12v-14 (manifestacja pasierbów z 13 I 1778 r.), 14, 17-17v (intromisja pasierbów z 14 I 1778 r.), 40v-41; APL, KgChL RMO, ks. 82, k. 648, 694, ks. 83, k. $81,124$.

103 APL, KgCh RMO, ks. 191, k. 380v-391v (akt condescensionis z 15-16 V 1789 r. z inwentarzem części kasztelaniców Ledóchowskich).

104 APL, KgChL RMO, ks. 105, k. 201-201v; APL, KgCh RMO, ks. 191, k. 486v-487, 487v-488v (inwentarz plebanii oraz gruntów i poddanych plebańskich w Uhrusku z 29 XII 1789 r.).

105 APL, KgCh RMO, ks. 191, k. 337, 341v, 377v-378,381v, 392, 532v, 855-857, 922v-923, 943, 1027 ; APL, KgChL RMO, ks. 105, k. 540; Boniecki A. 1900-1911, t. 5, s. 182; Urzędnicy bełscy. 1992, nr 800.

106 APL, KgChL RMO, ks. 114, k. 75 (wizja dworu w Uhrusku z 1796 r.); Szachałaj J. 2003, s. 55. 
się zmarł krótko przed 1810 r., gdy dożywotnio dzierżoną przez niego wieś Krasne przejął chorążyc smoleński, Dominik Antoni Drewnowski ${ }^{107}$.

O losach dzieci z dwóch pierwszych małżeństw Julianny wiemy niewiele. Z potomstwa z Michałem Wydżgą, wcześniej wspominana córka Franciszka, od 1770 r. żona Krzysztofa Dłużewskiego, zmarła młodo w 1774 r., zaś syn Walerian vel Walerian Andrzej był bez urzędów wymieniany w 1791 r., a później został sędzią tomaszowskim ${ }^{108}$. Drugi syn Florian Wydżga (zm. po 1820 r.) w listopadzie 1790 r. tytułowany podkomorzym królewskim, we wrześniu 1791 r. był komisarzem cywilno-wojskowym ziemi chełmskiej. W Księstwie Warszawskim od 1810 r. pełnił funkcję pierwszego prezesa Trybunału Cywilnego w Siedlcach, a w grudniu jeszcze tego samego roku awansował na sędziego apelacyjnego w Warszawie. Od 1797 r. był żonaty z Pelagią z Kosseckich, cześnikówną podolską ${ }^{109}$. Natomiast spośród dzieci zrodzonych z drugiego małżeństwa z Antonim Dłużewskim, syn Franciszek, urodzony w 1771 r., jeszcze we wrześniu $1791 \mathrm{r}$. wraz z matką i ojczymem zamieszkiwał we dworze w Woli Uhruskiej, a według Bonieckiego później ożenił się z Franciszką Kuroszówną. Natomiast dane o córkach są niepewne, jako że podawane były bez wymieniania rodziców. Zapewne jej córki, Barbary z Dłużewskich, dotyczy informacja z 26 lutego 1792 r. o złożeniu pozwu do sądu konsystorskiego łuckiego o unieważnienie małżeństwa z Antonim Onufrym Lipskim, szambelanem królewskim i starostą hnidawskim ${ }^{110}$. Możliwe też, że właśnie jej córką była Wiktoria z Dłużewskich, urodzona w 1776 a zmarła w 1826 r., żona Szymona Moraczewskiego, a następnie stolnika mielnickiego Antoniego Kajetana Kuczyńskiego z Kurowa i Hruszniewa ${ }^{111}$. Natomiast o ostatniej córce Katarzynie po 1779 r. w źródłach brak jakichkolwiek informacji. Można więc przypuszczać, iż zmarła w dzieciństwie.

W niniejszym tekście, zgodnie z tytułem, skupiliśmy się na traumatycznych przejściach Julianny Młodeckiej w dzieciństwie i we wczesnej młodości. Względna obfitość materiału źródłowego na ten temat wynika nade wszystko z faktu wykorzystania tej sprawy jako głównego dowodu obrony przed zarzutem porwania i przymuszenia siłą panny do wyjścia za mąż za Michała Wydżgę oraz w staraniach o rewindykację majątku po Aleksandrze Młodeckim, o czym była mowa powyżej. Gdyby w tych zabiegach kwestia nie została użyta instrumentalnie, nie jest pewne, czy zostałaby w jakikolwiek sposób udokumentowana. To zresztą, poza brakiem jakiegokolwiek zaprzeczenia ze strony obwinionej matki, waży na wiarygodności przedstawionych tam wydarzeń, potwierdzonych w składanych pod przysięgą zeznaniach świadków przed sądem konsystorskim. Niestety, w analizowanych archiwaliach trudno doszukać się przesłanek do odpowiedzi na nurtujące od początku pytanie: dlaczego to właśnie Julianna Młodecka stała się główną ofiarą sadystycznych skłonności matki? Cokolwiek nieprzekonująco brzmi twierdzenie jej samej podczas przesłuchania, że ,te codzienne męki i bicia nieznośne [...] aż do zabicia [...], to wszystko przez miłość [matki — W.B.] ku córce starszej, żeby większa porcja fortuny ojcowskiej dla jejm. [Franciszki - W.B.] Młockiej dostała się"112. Przecież rodzicielka mogła uczynić z nią to, co wcześniej stało się udziałem jej młodszej siostry Anny, czyli wysłać „bez niczego” do klasztoru i skutkowałoby to tym samym. Wobec tego siłą rzeczy pozostaje jedyne logiczne wytłumaczenie, że po „wypchnięciu” z domu pozostałego rodzeństwa, po prostu ostała się jako

107 Boniecki A. 1900-1911, t. 5, s. 16; Lipiński S. 2013, s. 324.

108 APL, KgCh RMO, ks. 191, k. 879v; Niesiecki K. 1841-1845, t. 10, s. 482.

109 APL, KgCh RMO, ks. 191, k. 618 (laudum sejmiku chełmskiego z 16 XI 1790 r.), 908; Boniecki A. 1900-1911, t. 11, s. 313; Bereza A., Okniński W. 2010, s. 27; Wereszycka H. 1969, s. 298; Załęski K. 2009, S. 220 .

110 APL, KgCh RMO, ks. 191, k. 486v, 908v, 1085-1085v (manifestacja o pozwie z 26 II 1792 r.); Boniecki A. 1900-1911, t. 14, s. 331-332.

111 Boniecki A. 1900-1911, t. 4, s. 299; Moraczewski S. 1907, s. 4; Tyszka A. 2001, s. 48.

112 APL, KgH RMO, ks. 48, k. 529v. 
jedyna (poza służbą) w zasięgu ciężkiej ręki terroryzującej otoczenie srogiej Litwinki. Wydaje się, że przynajmniej początkowo matce bardziej chodziło, aby „dogadzać swojej cholerze”, niźli zakatować dziewczynę na śmierć, czy „w męczarni [...] zamorzyć”"113.

Nie ulega wątpliwości, że okrutne, wręcz bestialskie traktowanie przez zwyrodniałą matkę musiało pozostawić ślad w psychice Julianny do końca życia. Jeszcze w manifestacji z 1775 r., a więc blisko trzydzieści lat po opuszczeniu domu — katowni, zarzucała Konstancji brak matczynego afektu. Znamienne, że w całym dokumencie nigdy nie została ona nazwana matką, lecz tylko żoną ojca ${ }^{114}$. Natomiast jak, w związku z takimi przeżyciami, później układały się relacje jej samej z własnymi dziećmi? Tego nie wiemy ze względu na brak odpowiednich źródeł. Można jedynie domniemywać, że zapewne nie najgorzej. Z pewnością szczególnie blisko była emocjonalnie związana z najstarszą córką Franciszką. Późniejsze losy Julianny po dramatycznej ucieczce z domu i pierwszym zamążpójściu zdają się już być typowe dla czasów, w których przyszło jej żyć. Nawet zwyczajne — a też chyba i ponadczasowe — okazywały się być spory majątkowe z dorosłym potomstwem jej dwóch pierwszych mężów z poprzednich małżeństw, przy jednoczesnych usilnych staraniach o zapewnienie możliwie najlepszego bytu własnym rodzonym dzieciom.

Adres Autora:

dr hab. Wiesław Bondyra

Instytut Historii

Uniwersytet Marii Curie-Skłodowskiej w Lublinie

pl. M. Curie-Skłodowskiej $4 \mathrm{a}$

20-031 Lublin

wieslaw.bondyra@poczta.umcs.lublin.pl

http://orcid.org/0000-0001-5813-777X

\section{BIBLIOGRAFIA}

\section{Źródla archiwalne}

AAL [Archiwum Archidiecezjalne w Lublinie], AKL [Akta Konsystorza Lubelskiego], sygn. Rep. 60 A128, AL 13.

AGAD [Archiwum Główne Akt Dawnych w Warszawie], AZ [Archiwum Zamojskich], sygn. 1367.

AGAD [Archiwum Główne Akt Dawnych w Warszawie], Kanclerskie [Księgi kanclerskie Metryki Koronnej], sygn. 47.

AGAD [Archiwum Główne Akt Dawnych w Warszawie], Sig. [Księgi sigillat Metryki Koronnej], sygn. 28, 29.

AGAD [Archiwum Główne Akt Dawnych w Warszawie], Zb.Czołow. [Zbiór A. Czołowskiego], sygn. 460.

APL [Archiwum Państwowe w Lublinie], KgL RMO [Księgi grodzkie chełmskie. Relacje, manifestacje, oblaty], ks. 169, 172, 175, 191.

APL [Archiwum Państwowe w Lublinie], KgChL RMO [Księgi grodzkie chełmskie. Relacje, manifestacje, oblaty. Luźne], ks. 70, 74, 77, 78, 82, 83, 105.

APL [Archiwum Państwowe w Lublinie], KgGR [Księgi grodzkie grabowieckie. Relacje], ks. 113.

APL [Archiwum Państwowe w Lublinie], KgGZ [Księgi grodzkie grabowieckie. Zapisy], ks. 129.

APL [Archiwum Państwowe w Lublinie], KgH RMO [Księgi grodzkie horodelskie. Relacje, manifestacje, oblaty], ks. 48, 49, 51.

\footnotetext{
113 APL, KgH RMO, k. 530v, 533.

114 APL, KgChL RMO, ks. 78, k. 45 (manifestacja z 8 II 1775 r.).
} 
APL [Archiwum Państwowe w Lublinie], KgK RMO [Księgi grodzkie krasnostawskie. Relacje, manifestacje, oblaty], ks. 47.

APL [Archiwum Państwowe w Lublinie], KgL RMO [Księgi grodzkie lubelskie. Relacje, manifestacje, oblaty], ks. 259, 272, 325.

APL [Archiwum Państwowe w Lublinie], KgLZ [Księgi grodzkie lubelskie. Zapisy], ks. 151, 159, $161,165$.

BN [Biblioteka Narodowa w Warszawie], Zb.Czołow. [Zbiory A. Czołowskiego], sygn. 5569, t. 4.

CPAHUK [Centralne Państwowe Archiwum Historyczne Ukrainy w Kijowie], f. 28 [fond 28: Księgi gr. włodzimierskie, opis 1], ks. 141.

CPAHUK [Centralne Państwowe Archiwum Historyczne Ukrainy w Kijowie], f. 49 [fond 49: Akta Potockich, opis 1], sygn. 139.

LNNBUL [Lwowska Narodowa Naukowa Biblioteka Ukrainy im. W. Stefanyka we Lwowie], f. 141 [fond 141: Zbiory A. Czołowskiego], sygn. 2429/III.

Stworzyński Mikołaj. 1834. „Opisanie statystyczno-historyczne dóbr Ordynacyi Zamojskiej w 1834 r.”, Biblioteka Narodowa w Warszawie, Biblioteka Ordynacji Zamojskiej, rkps 1815 (mps sygn. 1874 w Archiwum Państwowym w Lublinie).

\section{Źródła i opracowania publikowane}

Bereza Arkadiusz, Okniński Witold. 2010. Sąownictwo siedleckie. Tradycje i współczesność, Siedlce.

Bezzubik Edyta. 1999. Rapt w okresie staropolskim, „Studia Podlaskie”, t. 9, s. 65-72.

Bondyra Wiesław. 2003. Zarys dziejów Uhruska. 800 lat istnienia, [w:] Gmina Wola Uhruska na tle Euroregionu Bug. Język i kultura, red. F. Czyżewski, Wola Uhruska, s. 13-26.

Bondyra Wiesław. 2014. Urzędnicy grodzcy województwa betskiego i ziemi chetmskiej w czasach saskich. Spisy, [w:] Scientia nihil est quam veritas imago. Studia ofiarowane prof. R. Szczygłowi $w$ siedemdziesięciolecie urodzin, red. A. Sochacka, P. Jusiak, Lublin, s. 888-936.

Bondyra Wiesław. 2015. Własność ziemska w województwie bełskim w czasach saskich, Lublin.

Boniecki Adam. 1900-1911. Herbarz polski, t. 3-5, 14, Warszawa.

Deputaci. 2017. Deputaci Trybunatu Koronnego 1578-1794. Spis, cz. 4: 1701-1750, oprac. W. Bondyra, Lublin.

Elektorowie. 1908. Elektorowie królów Władysława IV, Michała Korybuta, Stanisława Leszczyńskiego i spis stronników Augusta III, wyd. J. Dunin-Borkowski, M. Dunin-Wąsowicz, „Rocznik Towarzystwa Heraldycznego we Lwowie", t. 1, 1908/1909.

Encyklopedia katolicka. 1985. Encyklopedia katolicka, t. 1, Lublin.

Encyklopedia kościelna. 1892. Encyklopedia kościelna, wyd. M. Nowodworski, t. 18, Warszawa.

Kitowicz Jędrzej. 1985. Opis obyczajów za panowania Augusta III, Warszawa.

Kosiński Adam Amilkar. 1881. Przewodnik heraldyczny, t. 3, Warszawa.

Księgi referendarii. 1979. Księgi referendarii koronnej z czasów saskich. Sumariusz, t. 2: 1735-1763, oprac. M. Woźniakowa, Warszawa.

Lipiński Stanisław. 2013. Przyczynek do dziejów Krasnego, „Rocznik Chełmski”, t. 17, s. 321-327.

Marczewski Jarosław. 2013. Dzieje chetmskiej kapituły katedralnej obrzadku łacińskiego, Lublin.

Metryki brygidek. 2011. Metryki brygidek lubelskich, oprac. J. Marczewski, Lublin.

Moraczewski Stanisław. 1907. Moraczewscy. Zarys genealogiczny z dokumentów urzędowych oraz papierów znajdujacych się w archiwum rodzinnym, Lwów.

Morys-Twarowski Michał. 2013. Uzupetnienia do biografii Michała Dzierżanowskiego (ok. 1722 -1809), „Zeszyty Naukowe Uniwersytetu Jagiellońskiego” Prace Historyczne, nr 140, z. 4, s. $313-320$.

Mozgawa Marek, Wrzyszcz Andrzej. 2019. Prawnokarna ochrona miru domowego na ziemiach polskich, „Ius Novum”, t. 13, nr 2, s. 75-106.

Niesiecki Kasper. 1841-1845. Herbarz polski, t. 6, 10, Lipsk.

Orłowski Ryszard. 1959. Opór włościan i formy walki klasowej w Ordynacji Zamojskiej w drugiej połowie XVIII stulecia, „Annales UMCS”, Sectio F, t. 14, s. 139-177.

Ostrowski Teodor. 1787. Prawo cywilne narodu polskiego, t. 1, Warszawa. 
Penkała Anna. 2017. Przeciw prawu, tradycji i obyczajowi. Sprawy procesowe szlacheckich matżeństw w księgach sądów grodzkich województwa krakowskiego w czasach saskich, Kraków.

Popiołek Bożena. 2014. Przemoc domowa w Polsce w pierwszej połowie XVIII w. w świetle ksiag sadowych, [w:] Scientia nihil est quam veritas imago. Studia ofiarowane prof. R. Szczygłowi $w$ siedemdziesięciolecie urodzin, red. A. Sochacka, P. Jusiak, Lublin, s. 978-990.

Popiołek Bożena. 2015. Męska zbrodnia, kobiecy ból? Drobna przemoc w czasach saskich, [w:] Kobieta i mężczyzna. Jedna przestrzeń - dwa światy, red. B. Popiołek, A. Chłosta-Sikorska, M. Gadocha, Warszawa, s. 83-93.

Popiołek Bożena. 2018. Kryminalia w księgach sądowych miast Korony jako źródło do badań nad życiem rodzinnym na przełomie XVII i XVIII wieku, „Kwartalnik Historii Kultury Materialnej”, R. LXVI, nr 1, s. 21-32.

Rolle Józef Apolinary. 1892. Po insurekcji kozackiej. Z wewnętrznych dziejów Bracławszczyzny, [w:] Rolle Józef Apolinary, Sylwetki historyczne, Seria 8, t. 8, Kraków, s. 115-268.

Sarcevičiene Jolita. 2014. „, Nie moga ich światobliwie wychowywać, jeśli onych nie gromia”. Relacje między rodzicami a dziećmi w piśmiennictwie XVIII wieku, [w:] W kręgu rodziny epok dawnych. Dzieciństwo, red. B. Popiołek, A. Chłosta-Sikorska, M. Gadocha, Warszawa, s. 397-414.

SGKP. 1883. Słownik geograficzny Królestwa Polskiego i innych krajów słowiańskich, t. 4, Warszawa.

Summariusz królewszczyzn. 1862. Summariusz królewszczyzn w całej Koronie Polskiej z wyrażeniem posesorów i siła która płaci rocznej kwarty, spisany roku 1770, wyd. E. Piotrowski, Żytomierz.

Szachałaj Jolanta. 2003. Historia parafii p.w. św. Jana Chrzciciela w Uhrusku (w świetle Wizytacji generalnej z 1799 r.), [w:] Gmina Wola Uhruska na tle Euroregionu Bug. Język i kultura, red. F. Czyżewski, Wola Uhruska, s. 53-59.

Tyszka Andrzej. 2001. Nekrologi „Kuriera Warszawskiego” 1821-1939, t. 1: 1821-1845, Warszawa.

Uruski Seweryn. 1914. Rodzina. Herbarz szlachty polskiej, t. 11, Warszawa.

Uruszczak Wacław. 2015. Historia państwa i prawa polskiego, t. 1: 966-1795, wyd. 3, Warszawa.

Urzędnicy bełscy. 1992. Urzędnicy województwa bełskiego i ziemi chełmskiej XIV-XVIII wieku. Spisy, oprac. H. Gmiterek, R. Szczygieł, Kórnik.

Urzędnicy lubelscy. 1991. Urzędnicy województwa lubelskiego XVI-XVIII wieku. Spisy, oprac. W. Kłaczewski, W. Urban, Kórnik.

Urzędnicy podlascy. 1994. Urzędnicy podlascy XIV-XVIII wieku. Spisy, oprac. E. Dubas-Urwanowicz, W. Jarmolik, M. Kulecki, J. Urwanowicz, Kórnik.

Urzędnicy ruscy. 1987. Urzędnicy województwa ruskiego XIV-XVIII wieku. Spisy, oprac. K. Przyboś, Wrocław.

Wereszycka Helena. 1969. Kossecki Stanisław, [w:] Polski Stownik Biograficzny, t. 14, Wrocław, s. 298.

Woliński Marek. 2011. Herbarz szlachty ziemi łukowskiej na Lubelszczyźnie, Szczecin.

Załęski Krzysztof. 2009. Słownik polskich prawników należacych do lóż wolnomularskich, „Ars Regia", nr 18, s. 181-223.

Zbudniewek Janusz. 1994. Fundacje paulinów w XVII i XVIII wieku, „Saeculum Christianum”, t. 1, nr 2, s. 65-82.

Żołądź-Strzelczyk Dorota. 2014. Przestrzeń dziecięca w staropolskiej rzeczywistości, [w:] W kręgu rodziny epok dawnych. Dzieciństwo, red. B. Popiołek, A. Chłosta-Sikorska, M. Gadocha, Warszawa, s. 213-236.

Żołądź-Strzelczyk Dorota, Kabacińska-Łuczak Katarzyna. 2012. Codzienność dziecięca opisana stowem i obrazem. Życie dziecka na ziemiach polskich od XVI do XVIII wieku, Warszawa.

Żychliński Teodor. 1880. Złota księga szlachty polskiej, t. 2, Poznań. 
The family oppression of Julianna Młodecka (1731-ca. 1799). A contribution to research on domestic abuse in the Old Polish times

The article presents the story of the unhappy childhood and early youth of Julianna Młodecka, daughter of Aleksander Młodecki, the Braclaw cupbearer, and his second wife Konstancja Wereszczakówna. After her father died and her mother married the Busk treasurer Józef Chociszewski, Julianna was treated in an inhumane way for several years; she was cruelly beaten and later also starved. Treated as a servant, she was forced to do housework and take care of her younger siblings; she was also denied education. After a few unsuccessful attempts, she finally managed to escape. To avoid returning under her mother's punishing hand, she decided to instantly marry her savior, the district scribe Michał Wydżga, who was much older than her. In the following years, he supported Julianna and her brother Kajetan in their attempts at regaining their inheritance. When her husband died, Julianna married another widower, the Krasnystaw huntsman Antoni Dłużewski. After both of her husbands' deaths, she had no choice but to feud with her grown-up stepsons about her life estate rights, in the interest of her own juvenile children. At the age of 58, she married her third husband, a lot younger than her, Antoni Dzierżanowski.

The article focuses primarily on Julianna's early life, up to her escape at the age of 16 . The details of her mother's bad-tempered ways were drawn from Julianna's and her husband's testimonies, confirmed by her brother and uncle, and especially from the sworn depositions and witnesses' accounts revealed during a hearing before the consistory court in Chełm.

Proofread by Izabela Szymańska 